Original Article

\title{
Study on Some Ectoparasitic Diseases of Catfish, Clarias gariepinus with their Control by Ginger, Zingiber officiale
}

\author{
J F. K. Abo-Esa \\ Parasitological Unit, Fish Diseases Research Department, Animal Health Research Institute, Egypt
}

\begin{abstract}
Parasitological investigation was performed in one hundred naturally collected Nile catfish Clarias gariepinus. It revealed skin and gill infestation with ectoparasitic protozoan Trichodina and Epistylis and monogenean Gyrodactylus spp. with average 20,15 and 25\%, respectively. The average of the total ectoparasitic infestation in the examined catfish was $60 \%$. The significance of herbal control measures using ginger Zingiber officiale as a new method to eradicate such parasites, was evaluated. A bioassay of 96 hours LC $_{50}$ of ginger emphasized that its value was $192 \mathrm{mg} / \mathrm{L}$. The herbal control with ginger was safe and effective to treat the ectoparasitic protozoa Trichodina and Epistylis spp. at dose 20mg/L, but not suitable for treating the monogenean Gyrodactylus spp. The estimation of dissolved oxygen, $\mathrm{pH}$ and total ammonia of aquarium water pre and during treatment was indicated that the use of ginger in aquaculture operation will improve its water quality especially the total ammonia.
\end{abstract}

Key Words: Clarias gariepinus, Trichodina spp., Epistylis spp., Gyrodactylus spp., Ginger, Aquaculture.

Received: 30 June 2007

Accepted: 16 October 2007

\section{Introduction}

The African catfish, Clarias gariepinus is one of the most important fish species for an economically successful aquaculture. However, farmers are constraint with massive fry and fingerling mortalities, especially in culture system due to the invasion of parasites. The protozoan Trichodina spp. and the monogenean Gyrodactylus spp. were the dominant parasites

\section{Correspondence:}

Jihan FathAlla Khalifa Abo-Esa

Parasitological Unit, Fish Diseases Research Department, Animal Health Research Institute,

Dokki, Giza, Egypt. Tel. : +2 0166544331 ,

E-mail: Dr.Jihan_f@Yahoo.com 
which were aggravated pathological effects on fish and increasing mortality (Akoll, 2005). Moreover, Kristmundsson et al. (2006) stated that the rearing environment with a subsequent increase in biomass and decreasing temperature caused a proliferation of trichodinids. Also, during parasitological surveys in Chogqing, China, Zhao and Tang (2007) investigated three trichodinids infesting a freshwater fish and a mollusc. Hubert and Warner (1975) recorded that Epistylis first appeared on the tips of both dorsal and pectoral fin spines. When untreated, Epistylis colonies spread and eventually covered much of the anterior region of the body and causes mortality of catfish. Paperna (1996) mentioned that fish heavily infested with Gyrodactylus appeared pale, due to excessive mucus secretion and epithelial proliferation. In the more heavily infested skin zones, there are skin erosion, desquamation of the skin epithelium, focal hemorrhagic lesions and severe mortalities. In addition, Boeger et al. (2005) reported that viviparous gyrodactylids exhibit extraordinary species diversity and broad host range if compared to other monogenean groups.

In the last few years, the herbal treatments were developed for replacing the chemical used for eradication of the most harmful parasites infesting terrestrial animals. In this respect, several herbs were used in pest and parasitic control as ginger which contains over four hundred chemically active ingredients, has long been used for treatment a variable diseases. It has a wide range of actions against parasites (Leo, 2001). In addition, Pro (2003) stated that ginger is the newest homeopathic treatment to be suggested. Practically, Colorni (1987) succeeded to treat fish infected with Cryptocaryon irritans with ginger for ten days with changing water every three days.

The present study was planned to endeavour of evaluating the possible use of new herbal control (Ginger) against some ectoparasitic protozoa and monogenea that infested Clarias gariepinus fish with calculating optimum dose that can completely eradicate these parasites by determination of the lethal concentration 50 of ginger and safety margin for such fish.

\section{Materials and Methods}

\section{Parasitological examination of fish:}

A total of 145 freshwater Clarias gariepinus ranged from 200-250g body weight were collected alive from El-Monib, Giza governorate fish market and transported immediately to the lab in large plastic bags partially filled with water and containing air according to Langdon and Jones (2002). The fish were examined for gross clinical signs and pathological lesion. The necropsy technique of parasitological examination of skin, fins and gills was carried out for the presence of external parasites with recording the average and intensity of the isolated parasites from one hundred catfish, the other 45 catfish were kept for applying the treatment. The recovered protozoa and monogenea were fixed, preserved and stained according to Paperna (1996), Langdon and Jones (2002).

\section{Ginger (Zingiber officiale):}

It was obtained as patent preparation in a Tablet form from MEPACO. Ginger is belonging to the Zingiberaceae plant family. Ginger contains several chemical components as outlined by Murray (1995): starch (50\%), protein (9\%), lipids (including glycerides, phosphatidic acid, lecithins, and fatty acids, 6-8\%), protease $(2.26 \%)$ and volatile oils (including gingerol, shogoal, zingiberene and zingiberol, 1-3\%). In addition, it contains vitamins $\mathrm{A}$ and $\mathrm{B} 3$ (niacin)

\section{Ginger lethal concentration-50 $\left(\mathrm{LC}_{50}\right)$ :}

A total number of 100 fish were divided into ten groups. The fish were exposed to different concentrations of ginger (Table 2), kept under observation for 96 hours and numbers of dead fish were recorded. The results were statistically analyzed according to Behrens and Karber (1953) by this equation:

\section{AXB}

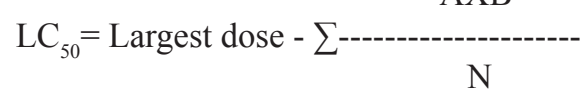


Where $\mathrm{A}$ is the mean of dead fish between two successive doses.

$\mathrm{B}$ is dose differences between two successive doses.

$\mathrm{N}$ is the total number of fish.

\section{Efficacy of ginger bath on the ectoparasites} infesting $C$.gariepinus:

A total of 45 alive naturally infested $C$. gariepinus were divided in three groups of 15 fish each in a volume of water $(100 \mathrm{x} 40 \mathrm{x} 15 \mathrm{~cm}$, 60 liters) with good aerated conditions. The safe level of ginger applied to infested fish was the 10 times lower than the value of ginger 96 hours LC $_{50}$ (Boyd 1998). It was approximately $20 \mathrm{mg} / \mathrm{L}$. The fish in the first group was exposed to $10 \mathrm{mg} / \mathrm{L}$ ginger while the second group was exposed to $20 \mathrm{mg} / \mathrm{L}$ ginger and the third group was considered a control.

\section{The water quality of fish aquarium before} and during treatment:

The fish were kept in the same volume of cleaned water (60-L for 15 fish) with good aeration and dechlorinated tap water, for at least one week before treatment. Water samples from each aquarium were analyzed at room temperature before and during treatment for estimating the dissolved oxygen, $\mathrm{pH}$ and total ammonia (Masser and Jensen, 1991). The dissolved oxygen was measured by Cole Parmer 5946-50oxygen meter, Analog field kit. The $\mathrm{pH}$ of water was measured by $\mathrm{pH}$ meter (Economy $\mathrm{pH} / \mathrm{mV} /$ ${ }^{\circ} \mathrm{C}$, Benchtop Meter) and the total ammonia was measured by the colorimeter apparatus (Model 6030-operating manual-Janway).

\section{Results}

\section{Gross macroscopic examination:}

The gross examination of infested fish with the isolated ectoparasitic protozoan, Trichodina, Epistylis and monogenean Gyrodactylus spp. revealed pale skin and excessive mucus secretion. Skin erosion with local hemorrhagic lesions was demonstrated in some infested fish (Fig. 1a\&b).

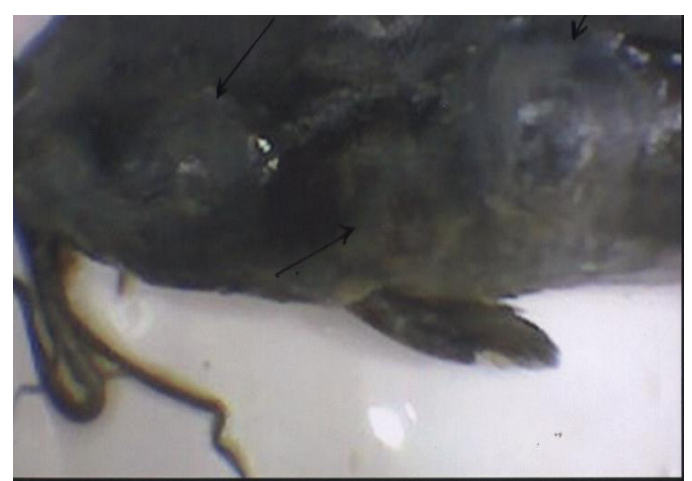

Fig. 1a: Clarias gariepinus showing pale mucus, erosions and ulceration in the skin.

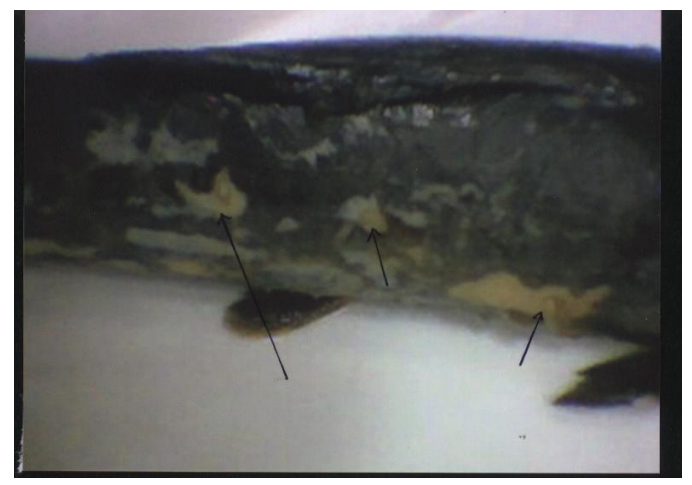

Fig. 1b: Clarias gariepinus showing pale mucus and ulcerative as well as erosive skin lesions.

\section{Parasitological examination:}

The parasitological examination revealed single and mixed infestation of some $C$. gariepinus with the ciliated ectoparasites Trichodina and Epistylis spp. in addition to monogenean ectoparasites Gyrodactylus spp. (Table 1).

Based on the morphological examination of the isolated ectoparasites, they were identified as the following:

\section{Ectoparasitic protozoa:}

- Phylum: Ciliophora

- Class: Ciliatea

- Subclass: Peritricha

- Order: Mobilina

- Family: Trichodinidae

- Genus: Trichodina

- $\quad$ Species: Trichodina species 
Table 1: Average and intensity of infestation with external parasites infested Clarias gariepinus.

\begin{tabular}{lccccc}
\hline \multicolumn{1}{c}{ Parasites } & $\begin{array}{c}\text { No of Examined } \\
\text { fish }\end{array}$ & $\begin{array}{c}\text { Total infested } \\
\text { fish \% }\end{array}$ & $\begin{array}{c}\text { Single } \\
\text { infestation } \%\end{array}$ & $\begin{array}{c}\text { Mixed infestation } \\
\%\end{array}$ & $\begin{array}{c}\text { Intensity of } \\
\text { infestation } \\
\text { No./ field (10X) }\end{array}$ \\
\hline Trichodina spp. & 100 & 60 & 20 & 30 & $8-10$ \\
Epistylis spp. & & & 25 & $15-18$ \\
Gyrodactylus spp. & & & $6-8$
\end{tabular}

Based on the morphological examination of the isolated ectoparasites, they were identified as the following:

\section{Ectoparasitic protozoa:}

- Phylum: Ciliophora

- Class: Ciliatea

- Subclass: Peritricha

- Order: Mobilina

- Family: Trichodinidae

- Genus: Trichodina

- $\quad$ Species: Trichodina species

Trichodina spp. is isolated from skin, fins and gills of infested C. gariepinus. It is large with disc shaped body. The adhesive disc is saucer shaped. The parasite is provided with several rows of cilia at the circular periphery and the inner circle of toothed denticles. The macronucleus is horse shoe-shaped and micronucleus is small and difficult to be seen in some specimens (Fig. 2).

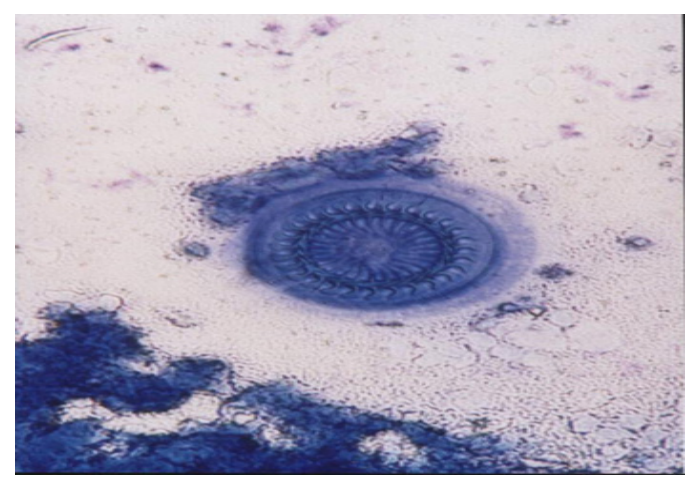

Fig. 2: Trichodina spp. isolated from the skin and of C. gariepinus (Stained with Giemsa's stain) (X400).
- Phylum: Ciliophora

- Class: Ciliatea

- Subclass: Peritricha

- $\quad$ Order: Peritrishida

- Suborder: Sessilina

- Phylum: Ciliophora

- Class: Ciliatea

- Subclass: Peritricha

- $\quad$ Order: Peritrishida

- Suborder: Sessilina

- Family: Epistylidae

- Genus: Epistylis

- $\quad$ Species: Epistylis spp.

Epistylis spp. is isolated from skin and gills of infested catfish. It is a sessile contractile ciliate. Stalk is long and non contractile. Often forms a branched colony. The distal end of the organism is surrounded by rapidly moving cilia which appear as a blur (Fig. 3).

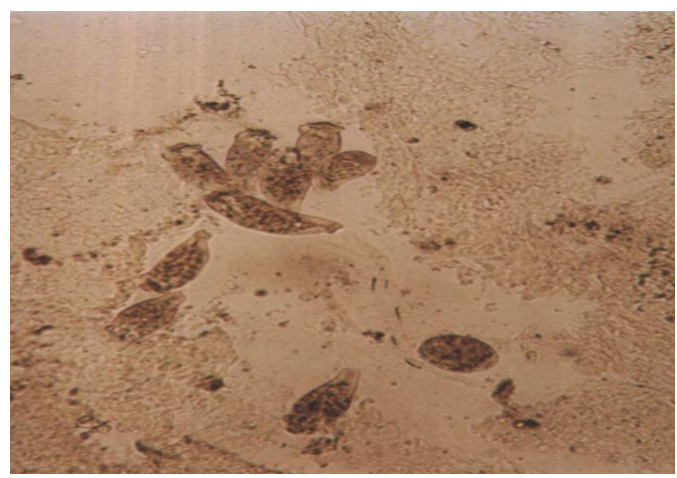

Fig. 3: Epistylis spp. recovered from the gills of C. gariepinus (wetpreparation) (X100). 


\section{Ectoparasitic monogenea:}

- Phylum: Platyhelminths

- Class: Dactylogyroidea

- Family: Gyrodactylidae

- Genus: Gyrodactylus

- $\quad$ Species: Gyrodactylus spp.

The monogenetic Gyrodactylus is detected in gills and skin of infested C. gariepinus. It is flat worm with one pair of projection at its anterior pole. It can be distinguished from other monogeneans by the absence of eye spots and the occurrence of the embryos in the mid-region of the body (Viviparous monogenean). Posterior end has the organ of fixation, opisthaptor, which is guarded with a number of marginal hooklets and a central one pair of hooks (Fig. 4, 5).

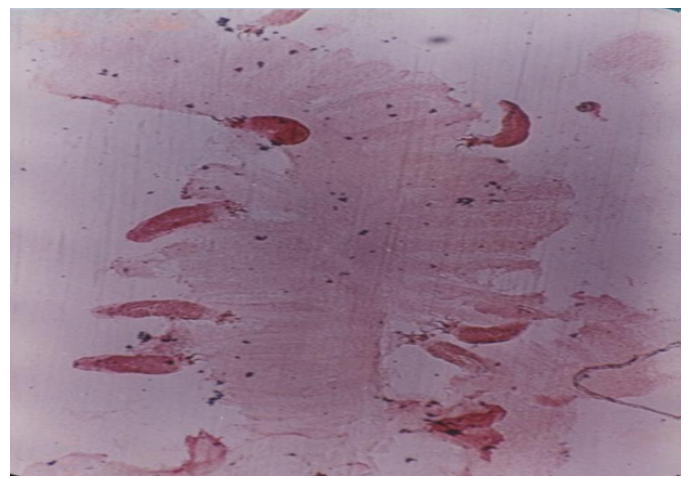

Fig. 4: Gyrodactylus spp. recovered from the gills of C. gariepinus (stained with Borax carmine stain) (X50).

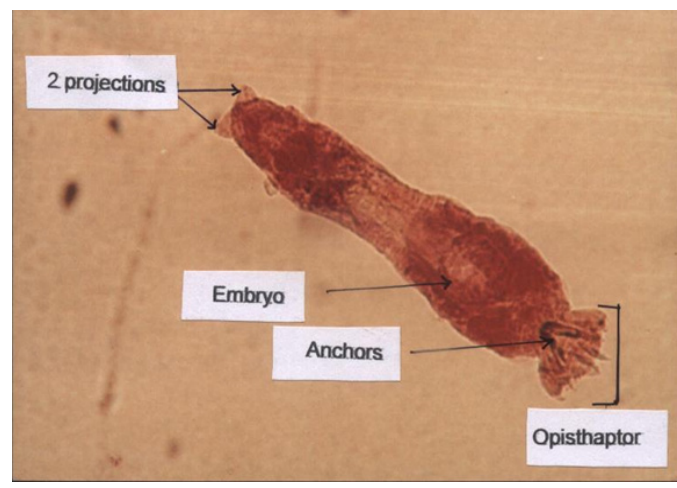

Fig. 5: Morphology and structure of recovered Gyrodactylus spp (stained with Borax carmine stain).

\section{Ginger lethal concentration-50 ( $\left.\mathrm{LC}_{50}\right)$ :}

The result of $\mathrm{LC}_{50}$ of ginger for $C$. gariepinus after 96 hours appeared to be $192 \mathrm{mg} / \mathrm{L}$ (Table 2).

Table 2: Conducting of ginger $\mathrm{LC}_{50}$ for Clarias gariepinus after 96 hours.

\begin{tabular}{cccccc}
\hline $\begin{array}{c}\text { Exposure } \\
\text { dose } \\
(\mathbf{m g} / \mathbf{L})\end{array}$ & $\begin{array}{c}\text { Fish } \\
\text { Numbers/ } \\
\text { groups }\end{array}$ & $\begin{array}{c}\text { No. of } \\
\text { dead } \\
\text { Fish }\end{array}$ & A & B & AXB \\
\hline 20 & & 0 & 0 & 0 & 0 \\
40 & & 0 & 0 & 0 \\
60 & & 1 & 0.5 & 1.5 & 10.0 \\
80 & & 2 & 1.5 & 30.0 \\
100 & 10 & 3 & 2.5 & 20 & 50.0 \\
120 & & 5 & 4 & & 80.0 \\
140 & & 7 & 6 & & 120 \\
160 & & 8 & 7.5 & & 150 \\
180 & & 9 & 8.5 & & 170 \\
200 & & 10 & 9.5 & & 190 \\
$\sum$ & 100 & & & & 800 \\
\hline
\end{tabular}

$\mathrm{LC}_{50}=192 \mathrm{mg} / \mathrm{L}$

(A) is the mean of dead fish between two successive doses.

(B) is dose differences between two successive doses.

\section{Efficacy of ginger bath on the ectoparasites infesting $C$. gariepinus:}

The results of ginger efficacy on the infested $C$. gariepinus with mixed infestation of Trichodina, Epistylis and Gyrodactylus spp. indicated that long exposure of infested fish for three days (long bath) to ginger at concentration $10 \mathrm{mg} / \mathrm{L}$ was insufficient to eradicate the protozoa and monogenea while ginger concentration of 20 $\mathrm{mg} / \mathrm{L}$ was sufficient to eradicate the protozoa (Trichodina and Epistylis spp.) but can not eradicate the monogenean (Gyrodactylus spp.) (Table 3). Overdose of ginger caused ulceration and erosion in the skin and fins of catfish (Fig. 6). 


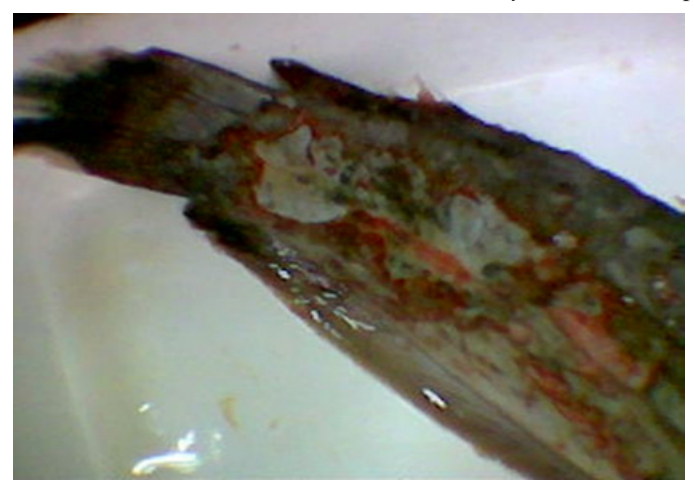

Fig. 6: Ulceration and bloody erosion in the skin and fins of C.gariepinus due to overdose of ginger.

\section{Estimation of the aquarium water quality before and during treatment:}

The estimation of water parameters (Dissolved oxygen, $\mathrm{pH}$ and total ammonia) pre and during treatment with ginger revealed that the water quality during treatment was better than pretreatment especiallythe total ammonia which decreased in value in comparing with pretreatment (Table 4).

\section{Discussion}

All ectoparasites appear to be an important pathological stressor affecting fish populations in the water stratum. In the present study, the gross clinical appearance of infested C. gariepinus with ectoparastic protozoa (Trichodina and Epistylis spp.) and the monogenean Gyrodactylus spp. demonstrated pale skin, excessive mucus secretion and skin erosion with local ulcerative lesions (Fig. 1a\&b). These results were similar to that recorded by (Kuperman and Matey, 2000 and El-Tantawy, 2001).

In Table (1), the total average of ectoparasites was $60 \%$. This result was lower than that of (ElTantawy, 2001) (100\% for protozoa and $76 \%$ for monogenea) in Oreochromis niloticus and higher than that recorded by Diab et al. (2006) as (44.4\%) among cultured $C$. gariepinus in Abassa. In addition, the average of the Trichodina spp. Fig. (2) in the infested catfish was $20 \%$ which was lower than the finding of Hanna (2001) who recorded Trichodina spp. from gills of common carp. With concern to Epistylis spp. Fig. (3), its average was $15 \%$. This result was lower than that recorded by El-Tantawy and Younis (2003) in Oreochromis niloticus (25\%).

The average of monogenean Gyrodactylus spp. Fig. $(4,5)$ was $30 \%$ among infested $C$. gariepinus. This result was lower than that obtained by (Endraws, 2001). Also, a higher average (100\%) was recorded by Paperna (1996) in the Nile fish. These variations in results might be attributed to the inhibitive quality of physical (Depth, current, temperature) and chemical (Oxygen, salinities) factors of the environment and fish species.

In the present study, the intensity of the ectoparasitic protozoa Trichodina, Epistylis and the monogenean Gyrodactylus spp. were 8-10, 15-18 and 6-8 parasites per field, respectively (Table 1). These numbers of ectoparasites per fish were considered a moderate infestation in O. niloticus as mentioned by El-Tantawy (2003). It may be attributed to that, in wild, catfish have many species of parasites with small numbers (FAO, 2007).

The taxonomy of the isolated Trichodina, Epistylis and Gyrodactylus spp. was typical to that reported by Paperna (1996), Huh et al. (2005) and Rotkiewicz (2006) Moreover, their morphological identification was similar to the description of El-khatib (1993), Lynn (2002) and Lome (2006).

In respect to the undesirable side effects of the chemical treatment of parasitic diseases and its public health hazards, the herbal treatment is taken place to relieve the harmful side effects of chemicals. So, in this study, the ginger was screened for its efficacy in treating $C$. gariepinus infested with a mixed infestation of Trichodina, Epistylis and Gyrodactylus spp. To avoid overdosing of ginger and to determine an effective control dose for ectoparasites, a bioassay of ginger $\mathrm{LC}_{50}$ after 96 hours was conducted (Table 2). The value of $192 \mathrm{mg} / \mathrm{L}$ ginger after 96 hours appeared to be its lethal concentration 50 for the exposed fish. So, the safe ginger dose must be $19.2 \mathrm{mg} / \mathrm{L}$ which is 10 times 
lower than such value as recommended by US Environmental protection Agency (Boyd, 1998) but in this study, the safe and effective dose of ginger for the exposed catfish was $20 \mathrm{mg} / \mathrm{L}$ which was approximately near the calculated safe dose $19.2 \mathrm{mg} / \mathrm{L}$. The higher ginger doses than 20 $\mathrm{mg} / \mathrm{L}$ caused various ulcerations and bloody erosions in the skin and fins of the treated fish (Fig. 6).

The efficacy of herbal treatment with ginger (long bath) on ectoparasites of catfish (Table 3 ) determined that the suitable dose of ginger for eradication of ectoparasitic protozoa Trichodina and Epistylis was $20 \mathrm{mg} / \mathrm{L}$ for three successive days. On the other hand, neither the doses of $10 \mathrm{mg} / \mathrm{L}$ nor $20 \mathrm{mg} / \mathrm{L}$ of ginger was sufficient to treat the monogenean Gyrodactylus spp. That dose of ginger used as protozoacid was in agreement with Boyd (1998) who recorded that the safe level recommended by US Environmental protection Agency are 10 to 100 times lower than the value of $96 \mathrm{hrs} \mathrm{LC}_{50}$. The pungent principles (including the volatile oil gingerol) are the most medicinally potent. It was performed to fish by Colorni (1987).

Concerning the impact of ginger on the water quality parameters, data shown in Table (4) revealed that the dissolved oxygen (5.6-6.7 ppm) was within its permissible limit (5-15 ppm) (Boyd, 1998). The $\mathrm{pH}$ values were approximately in the neutral range (6.92-7.2) in both pre and during treatment which is considered the ideal $\mathrm{pH}$ value for fish aquaculture operation (Noga, 2000). On the other hand, the recorded value of total ammonia (9-14.2 ppm) was much higher than its permissible limit $(<0.1 \mathrm{ppm})$ (Boyd, 1998). These results might be attributed to the carnivorous behavior of catfish species that metabolize more protein in their food and consequently more ammonia released in water as an end product of metabolism. However, the recovered level of total ammonia is unaffected in the presence of the recorded neutral $\mathrm{pH}$ value, meanwhile, in the presence of alkaline $\mathrm{pH}$, the more toxic free ammonia $\left(\mathrm{NH}_{3}\right)$ will increase in water (FAO, 2007). In addition, this

Table 3: Efficacy of ginger bath on ectoparasites infesting C. gariepinus.

\begin{tabular}{|c|c|c|c|c|c|}
\hline Fish groups & $\begin{array}{c}\text { Ginger doses } \\
\text { mg/l }\end{array}$ & $\begin{array}{c}\text { Period of } \\
\text { treatment/day }\end{array}$ & $\begin{array}{l}\text { Trichodina,spp. 8/ } \\
\text { field (10X) }\end{array}$ & $\begin{array}{c}\text { Epistylis,spp.18/ } \\
\text { field(10X) }\end{array}$ & $\begin{array}{c}\text { Gyrodactylus,spp. } \\
\text { 6/field(10X) }\end{array}$ \\
\hline \multirow{3}{*}{$1^{\text {st }}$ group } & \multirow{3}{*}{10} & 1 & 8 & 18 & 6 \\
\hline & & 2 & 6 & 10 & 5 \\
\hline & & 3 & 4 & 5 & 4 \\
\hline \multirow[t]{2}{*}{$2^{\text {st }}$ group } & \multirow[t]{2}{*}{20} & 1 & 5 & 6 & 6 \\
\hline & & 2 & 3 & 2 & 4 \\
\hline \multirow{4}{*}{$3_{(15)}^{\text {st }}$ group } & \multirow{4}{*}{ none-treated } & 3 & - & - & 3 \\
\hline & & 1 & 8 & 18 & 6 \\
\hline & & 2 & 11 & 18 & 6 \\
\hline & & 3 & 13 & 20 & 8 \\
\hline
\end{tabular}

Table 4: Estimation of some water parameters pre and during ginger treatment $(20 \mathrm{mg} / \mathrm{L})$.

\begin{tabular}{|c|c|c|c|c|}
\hline \multirow[t]{2}{*}{ Parameter } & \multicolumn{4}{|c|}{24 hours pre-treatment During treatment } \\
\hline & & $1^{\text {st }}$ day & $2^{\text {nd }}$ day & $3^{\text {rd }}$ day \\
\hline 1-Dissolved oxygen (PPM) & 5.6 & 6.4 & 6.5 & 6.7 \\
\hline 2- $\mathrm{pH}$ & 7.1 & 6.92 & 7.2 & 7.2 \\
\hline 3-Total ammonia (PPM) & 14.2 & 9 & 10.1 & 11.2 \\
\hline
\end{tabular}


study revealed that the values of total ammonia during applying ginger for three days $(9,10.1$ and $11.2 \mathrm{ppm}$, respectively) were lower than its value before treatment (14.2 ppm), these results proved the significant usage of ginger to improve the water quality.

\section{Conclusion}

Ginger has a good effect on treating ectoparasitic protozoa Trichodina and Epistylis spp. at dose $20 \mathrm{mg} / \mathrm{L}$. It also improves the water quality for aquaculture operation with absence of undesirable side effects in comparison to other chemicals used in this trend.

\section{References}

Akoll, P. 2005. Prevalence and pathology of protozoan and monogenean parasites in fry and fingerlings from cultured Clarias gariepinus (Burchell 1882) in Uganda, Sc.M. , Kampala, Uganda.

Behrines, A. \& Karber, L. 1965. Determination of $\mathrm{LD}_{50}$ in screening method in pharmacology, ed. R.A. Turner, Academic Press, New York.

Boeger, W.A., Kritsky, D.C. Pie, M.R. \& Engers, K.B. 2005. Mode of transmission, host switching, and escape from the Red Queen by viviparous gyrodactylids (Monogenoidea). The Journal of parasitology 91 (5): 1000-1007.

Boyd, C.E. 1998, Water quality for pond aquaculture, Alabama Agricultural Experiment Station, Auburn University, Alabama.

Colorni, A. 1987, Biology of Cryptocaryon irritans and strategies for its control. Aquaculture 67 (1/2): 236-237.

Diab, A.S., El-Bouhy, Z.M., Sakr, S.F. \& Abdel-Hadi, Y.M. 2006, Prevalence of some parasitic agents affecting the gills of some cultured fishes in Sharkia, Damietta and Fayium governorates, ISTA7, Arrizona, Mexico.

El-Khatib, R.H.N. 1993, Further studies on ectoparasitic infestation in freshwater, Faculty of Veterinary Medicine, Cairo University.
El-Tantawy, E.A. 2001, Efficacy of bio-clean for control of some ecto-parasites infesting Oreochromis niloticus in aquaculture, Veterinary Medical Journal 49 (4): 497-506.

El-Tantawy, E.A. 2003, Comparative study on the effect of formalin and garlic (Allium sativum) on ectoparasites infesting Oreochromis niloticus fish with reference to their effect on blood picture and serum constituants, Egyptian Journal of Agriculture Research 81 (1): 165-180.

Endrawes, M.N. 2001, Observations on some external and internal parasitic diseases in Nile catfishes, Faculty of Veterinary Medicine, Zagazig University.

FAO 2007. A handbook of diseases of cultured Clarias (Pla Duk) in Thailand, Food and Agriculture Organization of the United Nations (FAO).

Hanna, M.I. 2001. Epizootiological studies on parasitic infections in fishes cultured under different fish cultural systems in Egypt. M.Sc. Thesis, Faculty of Veterinary Medicine, Cairo University.

Hubert, W.A. ; Warner, M.C. 1975. Control of Epistylis on channel catfish in raceways, Journal of Wildlife Diseases 11 (2): 241-244.

Huh, M.D. Thomas, C.D., Udomkusonsri, P. \& Noga, E.J. 2005, Epidemic trichodinosis associated with severe epidermal hyperplasia in largemouth bass, Micropterus salmoides, from North Carolina, USA. Journal of Wildlife Diseases 41 (3): 647-653.

Kristmundsson, A., Eydal, M. \& Helgason, S. 2006. Progress of coinfections of Trichodina cooperi and $T$. murmanica parasitising farmed Atlantic cod Gadus morhua juveniles in Iceland, Diseases of Aquatic Organisms 71 (3): 213-223.

Kuperman, B.I. and Matey, V.E. 2000. Ectoparasites of fish and invertebrates of the Salton Sea, Center for Inland Waters and Department of Biology, San Diego State University, San Diego.

Langdon, J. and Jones, B. 2002. Design and implementation of health testing protocols for fish with special reference to sample size, test sensitivity and specifity, predictive value and risk, Australian Standard Diagnostic Techniques for Fish Diseases. 
Leo, G. 1998. Intestinal parasites, bacterial dysbiosis and leaky gut in Power healing: Use the new integrated medicine to cure yourself, ed. G. Leo, Random House.

Lome, J. 2006. Trichodinae and ciliates (Phylum: Ciliophora) in Fish diseases and disorders. Volume 1: Protozoan and metazoan infections, ed. P.T.K. Woo, $2^{\text {nd }}$ edn.

Lynn, D.H. 2002. Sessilids: Epistylis and Heteropolaria, The Ciliate Resource Archive. www.uoguelph.ca/ ciliates. htm

Masser, M.P. \& Jensen, J.W. 1991. Calculating treatments for ponds and tanks, Southern Regional Aquaculture Center.

Murray, M. 1995. The healing power of herbs, $2^{\text {nd }}$ edn, Prima Publishing, Roseville, CA.

Noga, E.J. 2000. Fish diseases: Diagnosis and treatment, Iowa State University Press.
Paperna, I. 1996. Parasites, infections and diseases of fishes in Africa: An update, CIFA Technical paper, no. 31, Fao. Rome. 220p.

Pro, S. 2003. Marine Ich/Cryptocaryon irritans: A discussion of this parasite and the treatment options available. Part II, Reef Central.

Rotkiewicz, P. 2006. ITIS taxonomy, Marine Biological Laboratory, Woods Hole.

Zhao, Y. and Tang, F. 2007. Trichodinid ectoparasites (Ciliophora: Peritricha) from Misgurnus anguillicaudatus (Cantor) and Anodonta woodiana (Lea) in China, with descriptions of two new species of Trichodina Ehrenberg, 1838, Systematic parasitology, 67 (1): 65-72. 